\title{
Experimental infection and pathology of two highly pathogenic avian influenza H5N1 viruses isolated from crow and chicken in house crows (Corvus splendens)
}

\author{
M. KUMAR, H. V. MURUGKAR, S. NAGARAJAN, C. TOSH, S. PATIL, K. H. NAGARAJA, \\ K. RAJUKUMAR, D. SENTHILKUMAR, S. C. DUBEY
}

ICAR-National Institute of High Security Animal Diseases, Anand Nagar, Bhopal, Madhya Pradesh, 462022, India

Received September 16, 2019; revised January 3, 2020; accepted July 24, 2020

\begin{abstract}
Summary.-We investigated the experimental infection of two highly pathogenic avian influenza H5N1 viruses isolated from crow (A/crow/Assam/142119/2008) and chicken (A/chicken/Sikkim/151466/2009) in house crows (Corvus splendens). Both viruses caused infection in crows, where four out of six and three out of six crows succumbed to H5N1 infection within 11 days post challenge by crow and chicken viruses, respectively. The major clinical signs in crows were wing paralysis, circling and torticollis. The virus shedding detected from swabs was not persistent in both crow nor chicken viruses. Both viruses were isolated more frequently from oral swabs than from cloacal swabs. Both virus strains were isolated from brain, lungs, heart, liver, pancreas, spleen, large intestines of crows that succumbed to H5N1 infection. The surviving birds seroconverted in response to H5N1 virus infection. Microscopically, both viruses caused coagulative necrosis in pancreas and kidneys. Brain showed gliosis and neuronal degeneration. This experimental study highlights that crows could be infected with H5N1 viruses from different hosts with minor differences in pathogenicity. Therefore, it is imperative to carry out surveillance of highly pathogenic avian influenza H5N1 virus in synanthropic birds along with biosecurity measures to mitigate the H5N1 spread in poultry population.
\end{abstract}

Keywords: chicken virus; crow virus; highly pathogenic avian influenza; house crows

\section{Introduction}

According to the World Organization for Animal Health (OIE), the H5N1 highly pathogenic avian influenza (HPAI) virus has spread to more than 60 countries affecting different species of birds and mammals since its emergence in 1996 from China (OIE, 2019). India reported first outbreak of H5N1 virus in February 2006 (Pattnaik et al., 2006). Since then the outbreaks were reported every year from different states of India till early 2019 (OIE, 2019). House crows (Corvus splendens) belonging to order Passeriformes are gregarious scavenger birds feeding on

E-mail: manojvet@gmail.com; phone: +917552759204. Abbreviations: $\mathrm{dpi}=$ days post inoculation; $\mathrm{HI}=$ hemagglutination-inhibition; HPAI = highly pathogenic avian influenza organic materials, dead and decomposed carcasses and dependent on human habitation (Ali, 2002). Crows can invade the poultry farms and are threat to poultry farming if $\mathrm{H} 5 \mathrm{~N} 1$ infected birds enter the farm. In 2008, the H5N1 virus was for the first time isolated from jungle crow in India(Nagarajan et al., 2010). The natural H5N1 outbreaks in crows have been reported from Japan, Bangladesh, and India (Khan et al., 2014; Nagarajan et al., 2010; Tanimura et al., 2006). Once the crow population becomes infected in a roost, the virus tends to circulate for longer period (Khan et al., 2014). The H5N1 virus causes heavy mortality in crows (Ellis et al., 2009). The crows might play an important role in epidemiology and ecology of H5N1 viruses. The pathogenicity of $\mathrm{H} 5 \mathrm{~N} 1$ virus in house crows is not fully understood. A recent study in crows revealed that jungle crows are highly susceptible to HPAIV H5N1 infection and virus was recovered from crows infected 


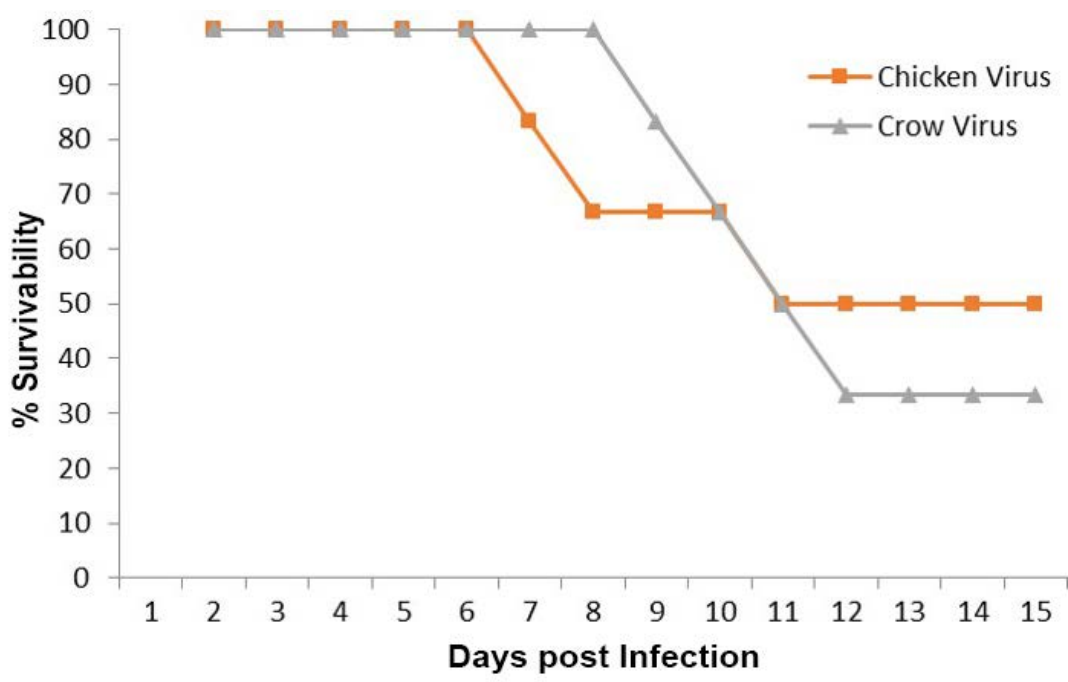

Fig. 1

Survival of the infected crows

Survivability rates of crows after A/crow/Assam/142119/2008 and A/chicken/Sikkim/151466/2009 H5N1 virus infection.

with HPAIVs, suggesting that they potentially play role in transmission of HPAIVs to poultry(Hiono et al., 2016). So, in the present study we conducted experiments in house crows to determine their susceptibility to infection and disease from two H5N1 viruses isolated from crows and chickens, pattern of oral and cloacal viral shedding; clinical signs and pathological changes.

\section{Materials and Methods}

Birds. The house crows for experimentation were procured from local market of Bhopal city with due approval from the Institute Animal Ethics Committee (IAEC) (No. 39/IAEC/ HSADL/10) and Institute Biosafety Committee (IBSC). The crows were transported to receiving animal facility of ICARNational Institute of High Security Animal Diseases (NIHSAD) and maintained in cages for 3 weeks for acclimatization. The crow food consisted of dried seeds, chicken eggs, chicken meat, home left-overs and water given adlibitum.

Viruses. We used highly pathogenic avian influenza H5N1 viruses of clade 2.2, A/crow/Assam/142119/2008 (crow virus) and A/chicken/Sikkim/151466/2009 (chicken virus), with a HA gene nucleotide homology of $97.85 \%$. The viruses were propagated in 9-11-day-old embryonated chicken eggs and 50\% egg infectious dose $\left(\right.$ EID $\left._{50}\right)$ was calculated for experiment.

Experiments. Six crows each were separately acclimatized for seven days in two isolators and inoculated intranasally with $100 \mu \mathrm{l}\left(10^{6} \mathrm{EID}_{50}\right)$ of $\mathrm{A} / \mathrm{crow} /$ Assam/142119/2008 and A/chicken/ Sikkim/151466/2009 H5N1 HPAI viruses in isolators maintained under negative pressure with HEPA filtration inside ABSL3 facility of ICAR-National Institute of High Security Animal Diseases. Three phosphate buffered saline inoculated control crows were housed in a separate isolator. Oral and cloacal swabs were collected daily from all crows for 14 days post inoculation (dpi) and stored at $-80^{\circ} \mathrm{C}$ until processing. The infected dead birds and euthanized controls and surviving infected birds were necropsied and tissues (brain, trachea, lungs, liver, intestines, kidneys, spleen and pancreas) were collected for virus isolation and histopathology.

Virus isolation. Swabs and triturated tissues were treated with $5 \mathrm{x}$ antibiotic and antimycotic solution (Sigma, USA) for $30 \mathrm{~min}$ at $37^{\circ} \mathrm{C}$ and clarified by centrifugation at $5000 \mathrm{xg}$. Samples were inoculated into 9-11-day-old embryonated specific pathogen free chicken eggs via allantoic and amniotic routes. The amino-allantoic fluid was harvested after incubation at $37^{\circ} \mathrm{C}$ for $72-96 \mathrm{~h}$ and clarified by centrifugation at $1,500 \mathrm{x} g$ for $15 \mathrm{~min}$ at $4^{\circ} \mathrm{C}$. The HA subtype of the virus was confirmed by hemagglutination-inhibition (HI) test (Nagarajan et al., 2009).

Histopathology. The 10\% neutral buffered formalin fixed tissues were processed for routine histopathology, sectioned at 5-6 $\mu \mathrm{m}$, and stained with haematoxylin and eosin.

Serology. The sera of crows before start of experiment were tested by ELISA for influenza A antibodies. The sera from euthanatized birds on the last day of experiments were also collected for $\mathrm{HI}$ test. All sera were inactivated at $56^{\circ} \mathrm{C}$ for $30 \mathrm{~min}$. The sera were then adsorbed with chicken red blood cells at room temperature for $1 \mathrm{~h}$ to reduce the nonspecific hemagglutination factors in crow serum. After centrifugation for removing chicken red blood cells, the sera were tested by the standard HI test using 4 hemagglutination units of the corresponding virus as antigen and $1 \%$ chicken red blood cell suspension(OIE, 2014). 


\section{Results}

Clinical signs, mortality and antibody response

Both viruses, crow and chicken virus, caused clinical signs and mortality in infected crows. Two out of six crows, (33.33\%) (Fig. 1) survived crow virus infection up to $14 \mathrm{dpi}$ and the death of four crows occurred within $11 \mathrm{dpi}$. The first death in crow virus infected birds occurred on $8^{\text {th }}$ $\mathrm{dpi}$, and the predominant clinical signs exhibited before death were wing paralysis, torticollis and circling movements. Respiratory signs, such as breathing difficulty or digestive signs, such as diarrhea, were not observed. Three out of six crows survived (50\%) (Fig. 1 ) chicken virus infection up to $14 \mathrm{dpi}$ and the mortality in crows started on $5^{\text {th }}$ dpi. The clinical signs such as torticollis, wing paralysis and circling movements were not as pronounced as those in crow virus. The surviving birds in both groups seroconverted as a response to corresponding viruses and the titers in crow virus infected birds was 16 . The HI antibody titers observed in crow and chicken virus infected birds 16 and 16 to 64 , respectively. No clinical signs or mortality during 14 days of observation were recorded in any of the control crows.

\section{Virus isolation from swabs and tissues}

The virus isolation from oral, cloacal swabs and from tissues of dead birds is summarized in table 1 . The virus was isolated from brain, trachea, lungs, liver, spleen and intestines of dead crows in both crow and chicken virus infected birds. The virus was not isolated from tissues of surviving crows after the observation period. The

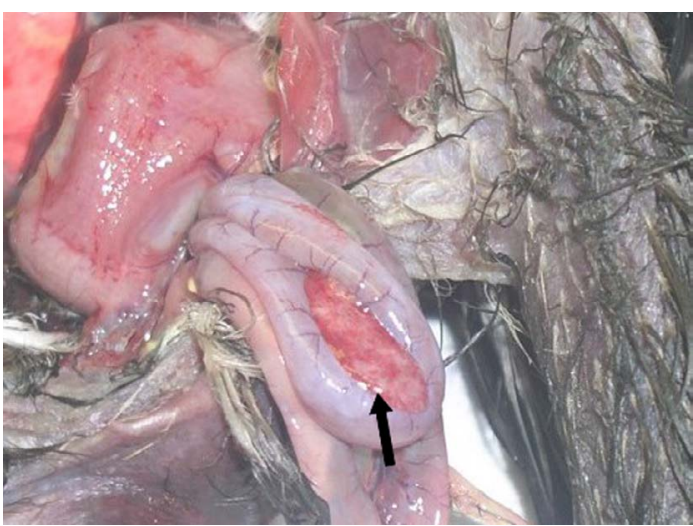

Fig. 2

Pancreas pathology of chicken virus infected crows Whitish foci present on pancreatic surface.

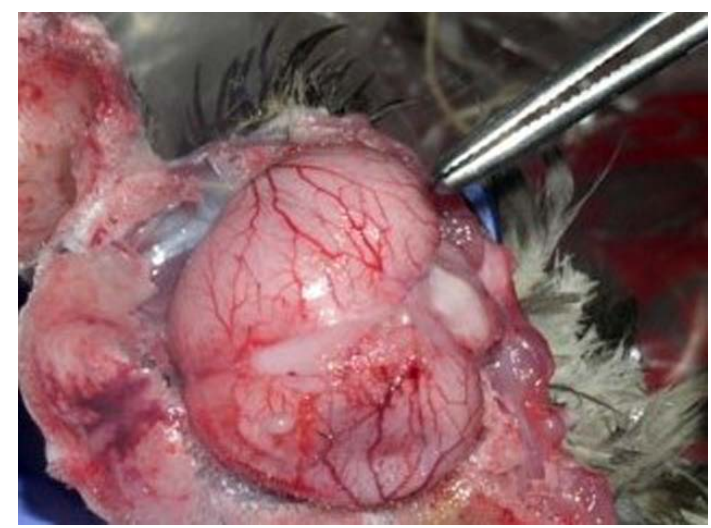

Fig. 3

Brain pathology of crow virus infected crows Meningeal congestion and hemorrhages in brain.

Table 1. Virus isolation from swabs and tissues

\begin{tabular}{|c|c|c|c|}
\hline Crow No. & Oral swabs & Cloacal swabs & Tissues \\
\hline \multicolumn{4}{|l|}{ A/crow/Assam/142119/2008 H5N1 virus } \\
\hline $1^{*}$ & $5-8$ days & - & brain, lungs, heart, liver, pancreas, spleen, large intestines \\
\hline $2^{*}$ & $7-8$ days & 6-8 days & brain, lungs, heart, liver, pancreas, spleen, large intestines \\
\hline $3^{*}$ & $7-8$ days & - & brain, lungs, heart, liver, pancreas, spleen, large intestines \\
\hline 4 & - & - & \\
\hline $5^{*}$ & 5-7 days & & brain, lungs, heart, liver, pancreas, spleen, large intestines \\
\hline 6 & - & - & \\
\hline & & - & \\
\hline \multicolumn{4}{|c|}{ A/chicken/Sikkim/151466/2009 H5N1 virus } \\
\hline 7 & - & - & \\
\hline $8^{\#}$ & $6^{\text {th }}$ day & - & brain, lungs, trachea, kidney, large intestine \\
\hline $9 \#$ & $6^{\text {th }}$ day & $6^{\text {th }}$ day & brain, lungs, trachea, heart, kidney, large intestine \\
\hline 10 & - & - & \\
\hline $11^{\#}$ & $6^{\text {th }}$ day & - & brain, lungs, trachea, kidney \\
\hline 12 & - & - & \\
\hline
\end{tabular}

"Crows 1, 2, 3 and 5 succumbed to infection from crow H5N1 virus. "Crows 8, 9 and 11 succumbed to infection from chicken H5N1 virus. 


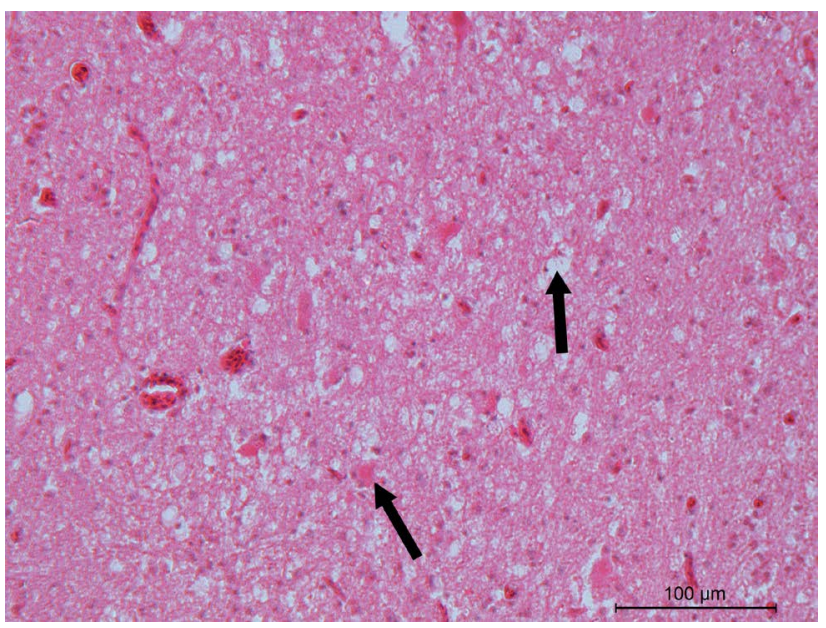

Fig. 4

Brain histopathology of crow virus infected crows Brain degenerating hypereosinophilic neurons showing chromatolysis, karyolysis and a spongy change in the neuropil. Bar: $100 \mu \mathrm{m}$.

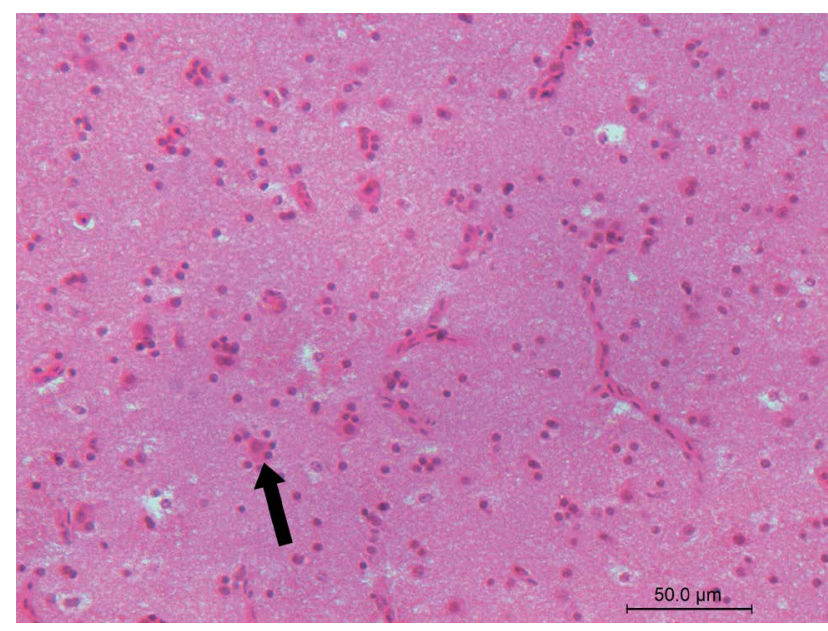

Fig. 5

Brain histopathology of chicken virus infected crows Brain swollen degenerating eosinophilic neurons along with satellitosis. Bar: $50 \mu \mathrm{m}$.

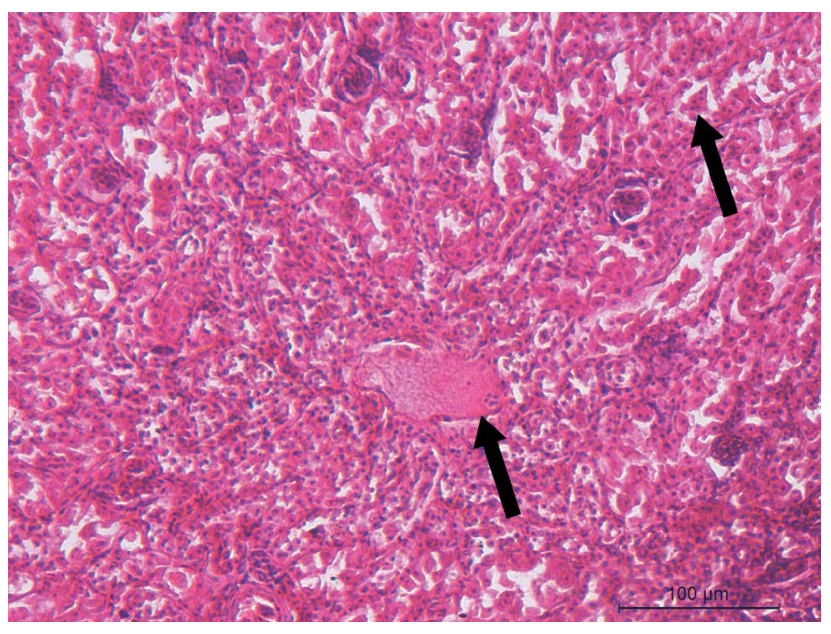

Fig. 6

Kidney histopathology of crow virus infected crows

Kidney diffuse interstitial congestion and hemorrhages and tubular epithelial cell degeneration and denudation into the lumen. A thrombus in renal blood vessel. Bar: $100 \mu \mathrm{m}$.

virus shedding in swabs was not persistent in any crow or chicken virus infected crows. The crow virus was isolated from oral swabs of four infected birds from $5^{\text {th }}-8^{\text {th }}$ $\mathrm{dpi}$; however, virus from cloacal swabs was isolated from $6^{\text {th }} 8^{\text {th }} d$ dpi from only one infected bird. The chicken virus was isolated from oral and cloacal swabs of three birds on $6^{\text {th }} \mathrm{dpi}$. The virus was isolated more frequently from oral swabs than cloacal swabs. The crow virus was present in more swab samples than the chicken virus.

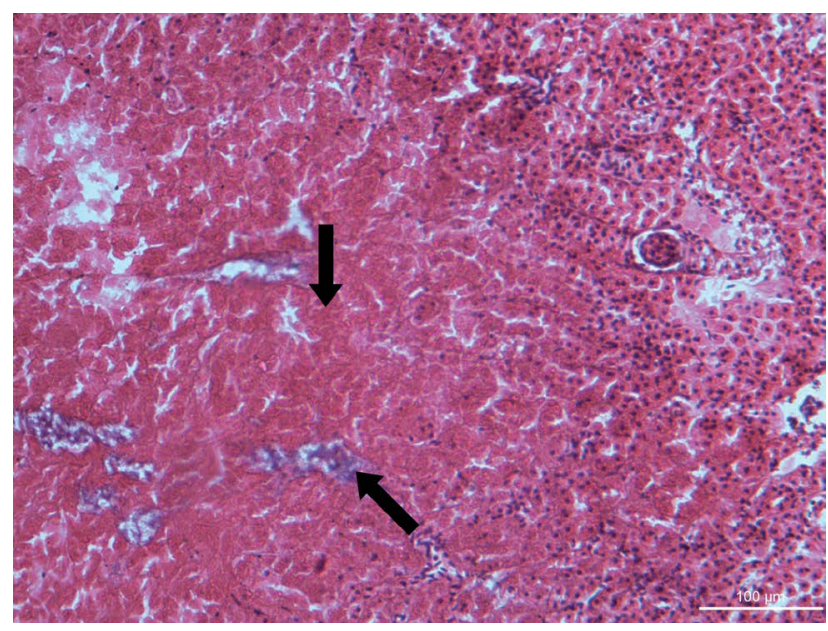

Fig. 7

Kidney histopathology of chicken virus infected crows Kidney acute focal coagulative necrosis of tubules and mineralization of renal parenchyma. Bar: $100 \mu \mathrm{m}$.

\section{Gross lesions and histopathology}

Both chicken and crow viruses caused consistent gross lesions in brain, pancreas and kidneys of dead birds, while all other organs did not show any significant lesions. The brain showed meningeal congestion; pancreatic surface had whitish foci; the kidneys were congested and had whitish foci on surface in both crow and chicken virus infected crows (Fig. 2 and 3). Histological lesions observed 
in haematoxylin and eosin stained tissues were most consistent in the brain, pancreas and kidneys. Brain of crow virus infected birds showed vascular congestion of meninges and neuropil, hypereosinophilic neurons with karyolysis and spongy change in neuropil (Fig.4). Diffuse gliosis along with perivascular infiltration was also observed in brain of dead crows. In chicken virus infected crows, cerebrum revealed swollen eosinophilic neurons along with satellitosis (Fig. 5). Kidneys of crow virus infected birds revealed vascular congestion, hemorrhages and tubular degeneration and denudation and thrombus in renal blood vessels (Fig. 6). In chicken virus infected crows, kidneys had thrombus and coagulative necrosis along with mineralization of parenchyma (Fig. 7) and in pancreas of infected birds coagulative necrosis of acinar cells without inflammatory cells was frequently observed. Other examined tissues showed only mild lesions such as sinusoidal congestion in liver, mild air capillary congestion in lungs and submucosal congestion in intestines. Control crows and surviving infected crows were healthy during the study period and did not reveal any gross and microscopic changes in the vital organs.

\section{Discussion}

Crows being synanthropic birds, can invade backyard and commercial poultry farms and if they invade an $\mathrm{H} 5 \mathrm{~N} 1$ infected farm they might be important carriers of avian influenza viruses. The $\mathrm{H} 5 \mathrm{~N} 1$ viruses isolated in India till 2010 belonged to clade 2.2 (Dubey et al., 2009; Tosh et al., 2011) and in 2009 for the first time clade 2.2 H5N1 virus was also isolated from a dead crow from Assam state in India(Nagarajan et al., 2010). Although there are a number of reports on experimental pathology of H5N1 viruses in chickens, only two reports of natural H5N1 infection in crows (Tanimura et al., 2006; Khan et al., 2014) and one experimental study of H5N1 in crows (Hiono et al., 2016) are available. So, herein, we examined pathology and virus excretion in house crows experimentally infected with two HPAI, H5N1 viruses isolated from crows and chickens, respectively, belonging to clade 2.2 . In this study, both crow and chicken viruses caused active infection and mortality in crows and killed four out of six and three out of six crows, respectively. These findings are corroborated by recent studies in crows (Hiono et al., 2016; Vijayakumar et al., 2015). The difference in mortality pattern in both of these viruses could be due to difference in virus origin. The pathogenicity of HPAIVs to in jungle crows also depends on the virus strains (Hiono et al., 2016). Clinical signs like circling and torticollis has also been reported in natural outbreak of H5N1 in crows in Bangladesh (Khan et al., 2014). Though, we have not determined the immune parameters in our experiment, the immune evasion could be the reason for disease and mortality observed in the present study in crows. The mortality in crows has been attributed to the evasion of innate immunity by $\mathrm{H} 5 \mathrm{~N} 1$ virus by attenuating interferon (IFN)-inducible signaling and altering the expression of toll-like receptors (TLRs) (Vijayakumar et al., 2015). The difference in clinical signs between two viruses observed in this experiment are in agreement with a study in jungle crows (Hiono et al., 2016). The shedding of viruses in cloacal and oropharyngeal swabs was not persistent (Table 1), which is in line with lack of persistent shedding of H5N1 virus observed in experimentally infected ducks(Wibawa et al., 2014). Earlier studies of H5N1 viruses in chickens, ducks and quails (Pantin Jackwood and Swayne, 2007) showed that oral shedding of virus is more pronounced than the cloacal shedding. Mounting of immune response as observed by seroconversion of surviving birds against HPAI H5N1 viruses was corroborated by similar response in sparrows, ducks and jungle crows (Hiono et al., 2016; Wibawa et al., 2014; Yamamoto et al., 2013). The antibody titer in surviving crows suggested active infection of crows with $\mathrm{H} 5 \mathrm{~N} 1$ viruses. The crow virus was isolated from brain, lungs, heart, liver, pancreas, spleen and large intestines of dead crows suggesting its pantropic nature. Chicken virus was also isolated from brain, lungs, trachea, heart, kidney and large intestine of dead crows which is in concurrence with the findings of natural outbreak of H5N1 in jungle crows (Tanimura et al., 2006). Gross lesions observed in brain, pancreas and kidneys in this experiment are different from study of natural outbreak of H5N1 in crows in Japan during 2006 (Tanimura et al., 2006). This could be due to different H5N1 viruses or the presence of bacterial infection in crows during outbreak in Japan. Microscopic lesions in brain, such as neuronal degeneration, neuronophagia, in pancreas focal acinar cell necrosis without inflammatory cell infiltration and focal necrosis in kidneys is in concurrence with earlier studies of HPAI H5N1 virus outbreaks in Japan and Bangladesh (Khan et al., 2014; Tanimura et al., 2006). Virus isolation from organs also explains these findings and crow deaths due to cell injury in these organs and pantropic nature of $\mathrm{H} 5 \mathrm{~N} 1$ viruses in crows.

In conclusion, this study highlights that crows can become infected with $\mathrm{H} 5 \mathrm{~N} 1$ viruses from different hosts with minor differences in pathogenicity. The virus shedding is not persistent however, virus could be isolated from different tissues which highlights the pantropic nature of $\mathrm{H} 5 \mathrm{~N} 1$ virus in crows. Due to cannibalism nature of crows, they can contract infection from $\mathrm{H} 5 \mathrm{~N} 1$ virus infected bird carcass. Infected crows could be a serious threat to poultry population due to incursion of crows in poultry farms. Hence, strict biosecurity measures and 
surveillance of influenza viruses in synanthropic birds is warranted to mitigate $\mathrm{H} 5 \mathrm{~N} 1$ spread.

Acknowledgments. Authors are thankful to Indian Council of Agricultural Research for funding the study under Outreach Program on Zoonotic Diseases (Project Reference No. OXX01585); Director, ICAR-Indian Veterinary Research Institute and Director, ICAR-NIHSAD for providing facilities to carry out the work.

\section{References}

Ali S (2002): The book of Indian birds. 13th ed. New Delhi: Bombay Natural History Society, Oxford University Press.

Dubey SC, Nagarajan S, Tosh C, Bhatia S, Lal Krishna (2009): Avian influenza: A long known disease and its current threat, Indian J. Ani. Sci. 79, 113-140.

Ellis TM, Dyrting KC, Wong CW, Chadwick B, Chan C, Chiang M, Li C, Li P, Smith GJ, Guan Y, Malik Peiris JS (2009): Analysis of H5N1 avian influenza infections from wild bird surveillance in Hong Kong from January 2006 to October 2007. Avian Pathol. 38, 107-119. https://doi. org/10.1080/03079450902751855

Hiono T, Okamatsu M, Yamamoto N, Ogasawara K, Endo M, Kuribayashi S, Shichinohe S, Motohashi Y, Chu DH, Suzuki M, Ichikawa T, Nishi T, Abe Y, Matsuno K, Tanaka K, Tanigawa T, Kida H, Sakoda Y (2016): Experimental infection of highly and low pathogenic avian influenza viruses to chickens, ducks, tree sparrows, jungle crows, and black rats for the evaluation of their roles in virus transmission, Vet. Microbiol. 182, 108-115. https://doi. org/10.1016/j.vetmic.2015.11.009

Khan SU, Berman La, Haider N, Gerloff N, Rahman Md Z, Shu Bo, Rahman M, Dey TK, Davis TC, Das BC, Balish A, Islam A, Jens P, Teifke, Zeidner N, Steven LS, Klimov A, Donis RO, Luby SP, Shivaprasad HL, Mikolon AB (2014): Investigating a crow die-off in January-February 2011during the introduction of a new clade of highly pathogenic avian influenza virus H5N1 into Bangladesh, Arch. Virol.159, 509-518. https://doi.org/10.1007/ s00705-013-1842-0

Nagarajan S, Rajukumar K, Tosh C, Ramaswamy V, Purohit K, Saxena, G, Behera, P, Pattnaik B, Pradhan HK, Dubey SC (2009): Isolation and pathotyping of H9N2 avian influenza viruses in Indian poultry, Vet. Microbiol.133, 154-163 https://doi.org/10.1016/j.vetmic.2008.06.013

Nagarajan S, Tosh C, Murugkar HV, Venkatesh G, Katare M, Jain R, Behera P, Khandia R, Tripathi S, Kulkarni DD, Dubey SC (2010): Isolation and molecular characterization of a H5N1 virus isolated from a Jungle crow (Corvus macrohynchos) in India. Virus Genes 41,30-36.https:// doi.org/10.1007/s11262-010-0477-4
OIE (World Organization for Animal Health), (2014) OIE terrestrial manual, Avian Influenza. Version adopted by the World Assembly of Delegates of the OIE in May 2014 OIE, Paris, France (Chapter 2.3.4).

OIE (World Organization for Animal Health), (2019) Update on highly pathogenic avian influenza in animals (types H5 and H7). http://www.oie.int/animalhealth- inthe- world/update-on-avian-influenza accessed on September 13, 2019.

Pantin-Jackwood MJ, Swayne DE (2007): Pathobiology of Asian highly pathogenic avian influenza $\mathrm{H} 5 \mathrm{~N} 1$ virus infections in ducks. Avian Dis. 51,250-259. https://doi. org/10.1637/7710-090606R.1

Pattnaik B, Pateriya AK, Khandia R, Tosh C, Nagarajan S, Gounalan S, Murugkar HV, Shankar BP, Shrivastava N, Behera P, Bhagat S, Peiris JSM, Pradhan HK (2006) Phylogenetic analysis revealed genetic similarity of the H5N1 avian influenza viruses isolated from HPAI outbreaks in chickens in Maharashtra, India with those isolated from swan in Italy and Iran in 2006, Curr. Sci. 91, 77-81.

Tanimura N, Tsukamoto K, Okamatsu M, Mase M, Imada T, Nakamura K, Kubo M, Yamaguchi S, Irishio W, Hayashi M, Nakai T, Yamauchi A, Nishimura M, Imai K (2006): Pathology of fatal highly pathogenic H5N1 avian influenza virus infection in large-billed crows (Corvus macrorhynchos) during the 2004 outbreak in Japan, Vet. Pathol.43,500-509. https://doi.org/10.1354/vp.434-500

Tosh C, Nagarajan S, Murugkar HV, Jain R, Behera P, Katare M, Kulkarni DD, Dubey SC (2011): Phylogenetic evidence of multiple introduction of $\mathrm{H} 5 \mathrm{~N} 1$ virus in Malda district of West Bengal, India in 2008. Vet. Microbiol. 148, 132-139. https://doi.org/10.1016/i.vetmic.2010.08.015

Vijayakumar P, Mishra A, Ranaware PB, Kolte AP, Kulkarni DD, Burt DW, Raut AA (2015): Analysis of the crow lung transcriptome in response to infection with highly pathogenic H5N1 avian influenza virus. Genes 559, 77-85. https://doi.org/10.1016/i.gene.2015.01.016

Wibawa H, Bingham J, Nuradji H, Lowther S, Payne J, Harper J, Junaidi A, Middleton D, Meers J (2014): Experimentally Infected Domestic Ducks Show Efficient Transmission of Indonesian H5N1 Highly Pathogenic Avian Influenza Virus, but Lack Persistent Viral Shedding. PLoS ONE 9, e83417. https://doi.org/10.1371/journal. pone. 0083417

Yamamoto Yu, Nakamura K, Yamada M, Mase M (2013): Pathogenesis in Eurasian Tree Sparrows Inoculated with H5N1 Highly Pathogenic Avian Influenza Virus and Experimental Virus Transmission from Tree Sparrows to Chickens. Avian Dis. 57, 205-213. https://doi. org/10.1637/10415-101012-Reg.1 